\title{
Evapotranspiration, yield, crop coefficients, and water use efficiency of drip and furrow irrigated processing tomatoes
}

\author{
B. Hanson \& D. May \\ Department of Land, Air and Water Resources, \\ University of California, Davis, USA
}

\begin{abstract}
A key component of sustainable agriculture is maintaining profitable yields, which involves applying sufficient water to meet a crop's evapotranspiration $\left(E T_{c}\right)$ requirements. This requires knowledge of the current $E_{c}$ requirement. Yield of processing tomatoes has increased by $53 \%$ over the past 35 years in California. Thus, concern exists about the current ETc and crop coefficients of processing tomatoes. Past irrigation practices were furrow and sprinkle irrigation, whereas drip irrigation is now commonly used in some parts of the state. Thus, the Bowen Ratio energy balance method was used in eight commercial fields to determine current seasonal $\mathrm{ET}_{\mathrm{c}}$, crop coefficients, and water use efficiency for furrow and drip irrigated fields. Results showed seasonal crop evapotranspiration to range from $528 \mathrm{~mm}$ to $752 \mathrm{~mm}$ with an average of 648 $\mathrm{mm}$. Commercial yields ranged from $78.6 \mathrm{Mg} \mathrm{ha}^{-1}$ to $146.7 \mathrm{Mg} \mathrm{ha}^{-1}$. Water use efficiency ranged between $0.114 \mathrm{Mg} \mathrm{ha}^{-1} \mathrm{~mm}^{-1}$ to $0.235 \mathrm{Mg} \mathrm{ha}^{-1} \mathrm{~mm}^{-1}$. No statistical differences in seasonal $\mathrm{ET}_{\mathrm{c}}$, yield, and water use efficiency were found between furrow and drip irrigation. Mid-season crop coefficients varied from 0.96 to 1.09 depending on year with statistically similar values between furrow and drip irrigation for a given year. Current $\mathrm{ET}_{\mathrm{c}}$ rates were similar to those of the 1970s. Thus, average water use efficiency of processing tomatoes increased from $0.082 \mathrm{Mg} \mathrm{ha}^{-1} \mathrm{~mm}^{-1}$ to $0.12 \mathrm{Mg} \mathrm{ha}^{-1} \mathrm{~mm}^{-1}$ over the 35 year period.
\end{abstract}

Keywords: evapotranspiration, processing tomatoes, drip irrigation, furrow irrigation, water, irrigation, tomato, water use, water use efficiency, crop coefficients. 


\section{Introduction}

A key component of sustainable agriculture is maintaining profitable crop yields. It is well established that crop yield is strongly dependent on seasonal crop evapotranspiration $\left(\mathrm{ET}_{\mathrm{c}}\right)$. A profitable yield of processing tomatoes requires supplying sufficient irrigation water to satisfy $\mathrm{ET}_{\mathrm{c}}$. Thus, it is critical to know the current seasonal $\mathrm{ET}_{\mathrm{c}}$ of processing tomatoes for sustainability.

The average state-wide yield of processing tomato per unit area increased from 53.0 $\mathrm{Mg} \mathrm{ha}^{-1}$ during 1970 - 1974 to $81.3 \mathrm{Mg} \mathrm{ha}^{-1}$ during 2000 - 2004, a 53 percent yield increase [1]. During the 1970s, calculated seasonal $\mathrm{ET}_{\mathrm{c}}$ ranged from $637 \mathrm{~mm}$ to $714 \mathrm{~mm}$ with an average seasonal value of $645 \mathrm{~mm}$ [2].

$\mathrm{ET}_{\mathrm{c}}$ is commonly estimated by multiplying a crop coefficient by a reference crop evapotranspiration $\left(\mathrm{ET}_{\mathrm{o}}\right)$. Measured mid-season crop coefficients, developed 20 to 35 years ago from experimental data, ranged from 1.05 under subsurface drip irrigation [3] to 1.25 under sprinkler irrigation [4].

The long term yield increase coupled with the variability in crop coefficients determined from experimental data 20 to 35 years old raises questions about current $\mathrm{ET}_{\mathrm{c}}$ requirements. This study evaluated $\mathrm{ET}_{\mathrm{c}}$, yield, crop coefficients, and water use efficiency of processing tomato on the west side of the San Joaquin Valley of California for furrow-and drip-irrigated commercial fields under a wide range of cultural practices experienced by growers.

\section{Materials and methods}

$\mathrm{ET}_{\mathrm{c}}$ of processing tomato was determined from 2001 to 2004 for three furrowirrigated and five drip-irrigated commercial fields located on the west side of the San Joaquin Valley near Five Points, CA. ET $_{\mathrm{c}}$ was determined with the Bowen Ratio Energy Balance Method (BREB). Other data collected were soil water potential (Watermark electrical resistance blocks), canopy coverage (infrared digital camera), yield and soluble solids (commercial grading station), and applied water.

Fields were selected to obtain a wide range of cultural practices. Planting times ranged from 1 March to 25 May. Transplants in some fields, while others were direct-seeded. Sprinkle irrigation was used for stand establishment in six fields, while subsurface drip irrigation was used in two fields. Crop season ranged from 109 days to 147 days. Soil type was clay loam for all fields. Subsurface drip irrigation was used with drip lines buried $0.2 \mathrm{~m}$ to $0.36 \mathrm{~m}$ deep.

Crop coefficients were calculated as the ratio of $\mathrm{ET}_{\mathrm{c}}$ to $\mathrm{ET}_{\mathrm{o}} \mathrm{ET}_{\mathrm{o}}$ was obtained from the California Irrigation Management Information System (CIMIS) station located at the University of California Westside Research and Extension Center, about 5 to $8 \mathrm{~km}$ from the eight fields. Water use efficiency was calculated as the ratio of yield to $\mathrm{ET}_{\mathrm{c}}$.

\section{Results and discussion}

Seasonal crop $\mathrm{ET}_{\mathrm{c}}$ ranged from $528 \mathrm{~mm}$ to $752 \mathrm{~mm}$ with an average of $648 \mathrm{~mm}$ (Table 1). Average $\mathrm{ET}_{\mathrm{c}}$ was $620 \mathrm{~mm}$ and $696 \mathrm{~mm}$ for drip and furrow irrigation, 
respectively. The difference in the average seasonal $\mathrm{ET}_{\mathrm{c}}$ between irrigation methods was not statistically significant (t-test, level of significance of 0.05). Applied water ranged from $582 \mathrm{~mm}$ to $1018 \mathrm{~mm}$ (Table 1). The furrow irrigation amounts included surface runoff that was recovered and reused elsewhere on the farms.

Crop yield ranged from 78.6 $\mathrm{Mg} \mathrm{ha}^{-1}$ to $146.7 \mathrm{Mg} \mathrm{ha}^{-1}$ (Table 1). The difference in average yields between irrigation methods was not statistically significant. No correlation occurred between crop yield and ETc, mainly due to the different varieties and site conditions of this study.

Water use efficiency (WUE) ranged from $0.11 \mathrm{Mg} \mathrm{ha}^{-1} \mathrm{~mm}^{-1}$ to $0.23 \mathrm{Mg} \mathrm{ha}^{-1}$ $\mathrm{mm}^{-1}$ (Table 1). The average WUE was $0.13 \mathrm{Mg} \mathrm{ha}^{-1} \mathrm{~mm}^{-1}$ and $0.16 \mathrm{Mg} \mathrm{ha}^{-1}$ $\mathrm{mm}^{-1}$ for furrow and drip irrigation, respectively, but these values were not statistically different based on the t-test (level of significance $=0.05$ ).

Table 1: $\quad$ Seasonal $\mathrm{ET}_{\mathrm{c}}$, applied water, crop yield, and water use efficiency (WUE).

\begin{tabular}{|l|c|c|c|c|}
\hline & $\begin{array}{c}\text { Seasonal } \\
\mathrm{ET}_{\mathrm{c}} \\
(\mathrm{mm})\end{array}$ & $\begin{array}{c}\text { Applied } \\
\text { Water } \\
(\mathrm{mm})\end{array}$ & $\begin{array}{c}\text { Yield } \\
\left(\mathrm{Mg} \mathrm{ha}^{-1}\right)\end{array}$ & $\begin{array}{c}\text { WUE } \\
\left(\mathrm{Mg} \mathrm{ha}^{-1} \mathrm{~mm}^{-1}\right)\end{array}$ \\
\hline \multicolumn{5}{|c|}{2001} \\
\hline Furrow & 648 & 836 & 86.2 & 0.129 \\
\hline Drip & 571 & 582 & 93.6 & 0.159 \\
\hline \multicolumn{5}{|l|}{2002} \\
\hline Furrow & 688 & 660 & 78.6 & 0.110 \\
\hline Drip & 742 & 764 & 87.8 & 0.115 \\
\hline \multicolumn{5}{|l|}{2003} \\
\hline H2003 (drip) & 622 & 803 & 146.7 & 0.228 \\
\hline D2003 (drip) & 528 & 894 & 91.2 & 0.167 \\
\hline \multicolumn{5}{|l|}{2004} \\
\hline Furrow & 752 & 1018 & 116.4 & 0.150 \\
\hline Drip & 630 & 625 & 82.1 & 0.124 \\
\hline
\end{tabular}

During the sprinkle irrigation for stand establishment, maximum crop coefficients ranged from 0.91 to 1.21 with an average maximum coefficient of 1.03. The average crop coefficient between sprinkle irrigation and $10 \%$ canopy coverage was 0.19 . Crop coefficients at the start of the crop season were smaller than 0.3 for sites where subsurface drip irrigation was used for stand establishment. Average mid-season crop coefficients varied from year to year with values ranging from 0.96 to 1.09 (Table 2). No statistical differences were found between the mid-season crop coefficients of the two irrigation methods for a given year; however, differences were significant between years.

Crop coefficients $\left(\mathrm{K}_{\mathrm{c}}\right)$ were related to canopy coverage $(\mathrm{C})$ by a second-order polynomial equation (Fig. 1; Eq. 1). The regression was highly significant with a coefficient of determination of 0.96 .

$$
\mathrm{K}_{\mathrm{c}}=0.126+(0.0172)(\mathrm{C})-(0.0000776)\left(\mathrm{C}^{2}\right)
$$


Table 2: $\quad$ Average daily mid-season crop coefficients for each year. (SD = standard deviation.) Values with the same letter were statistically similar at a level of significance of 0.05 , based on the t-test.

\begin{tabular}{|l|c|c|c|c|c|c|c|c|}
\hline & \multicolumn{2}{|c|}{2001} & \multicolumn{2}{c|}{2002} & \multicolumn{2}{c|}{2003} & \multicolumn{2}{c|}{2004} \\
\hline & Furrow & Drip & Furrow & Drip & Drip & Drip & Furrow & Drip \\
\hline Ave. & $1.02 \mathrm{ab}$ & $0.96 \mathrm{~b}$ & $1.06 \mathrm{c}$ & $1.05 \mathrm{ac}$ & $1.05 \mathrm{c}$ & $0.99 \mathrm{ab}$ & $1.09 \mathrm{~d}$ & $1.08 \mathrm{~d}$ \\
\hline SD & 0.04 & 0.05 & 0.04 & 0.06 & 0.04 & 0.11 & 0.04 & 0.02 \\
\hline Min. & 0.92 & 0.84 & 0.96 & 0.92 & 0.96 & 0.72 & 0.93 & 1.02 \\
\hline Max. & 1.11 & 1.07 & 1.13 & 1.30 & 1.15 & 1.19 & 1.16 & 1.14 \\
\hline
\end{tabular}

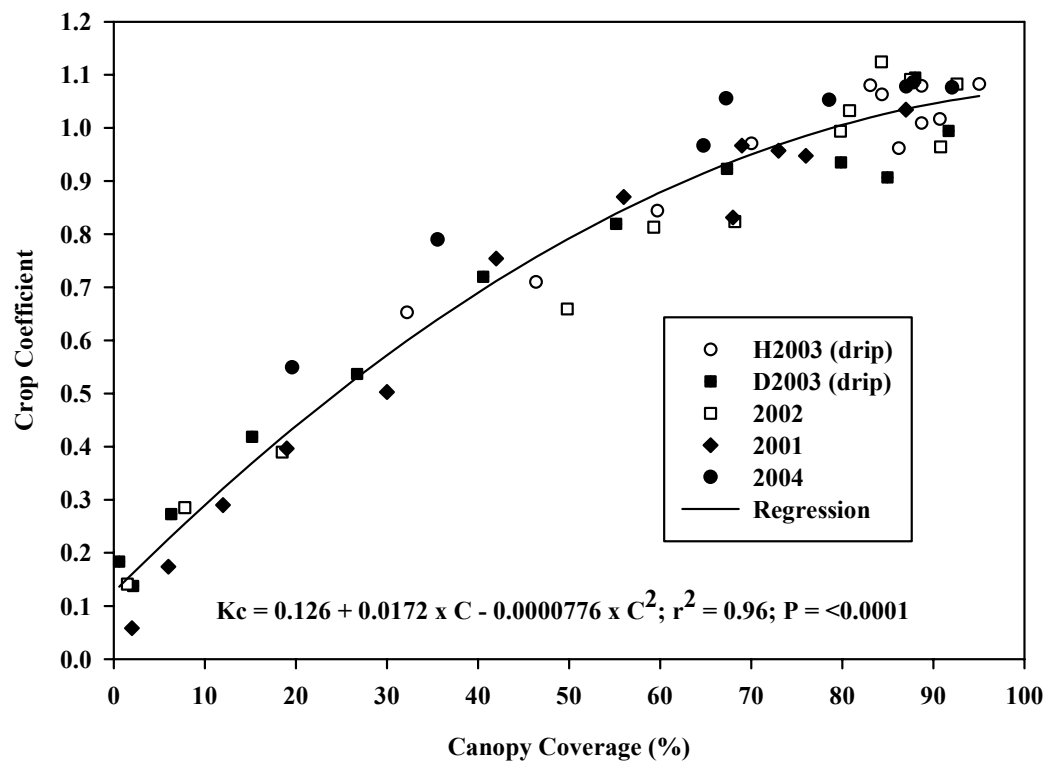

Figure 1: Crop coefficient as a function of canopy coverage.

It has been hypothesized that the seasonal $\mathrm{ET}_{\mathrm{c}}$ of subsurface drip irrigation is smaller than that of furrow irrigation due to reduced evaporation from the soil. The only study found on this matter showed little difference in seasonal $\mathrm{ET}_{\mathrm{c}}-$ measured with lysimeters - between surface drip and furrow irrigation of processing tomatoes [5].

The only conclusion that can be drawn from our current study is that evaporation under subsurface drip irrigation may be smaller during the early growth stages compared to furrow irrigation, as occurred in 2001 (data not shown). For the 2001 furrow system, relatively high evaporation occurred during both the stand-establishment sprinkle irrigation and the furrow irrigations of the canopy development stage, as evidenced by crop coefficients nearly equal to one during these irrigations (data not shown). During those irrigations, wetting of the soil surface across the bed width occurred due to excessive irrigation times. In 
contrast, little surface wetting occurred with the subsurface drip system. Cumulative $\mathrm{ET}_{\mathrm{c}}$ at the end of the canopy development stage was $117 \mathrm{~mm}$ higher for the furrow system as compared to the subsurface drip system. The behaviour of the 2001 furrow system, however, was not found during the canopy development stages of the 2002 and 2004 furrow systems because these systems were managed to minimize soil-surface wetting.

\section{Conclusions}

No difference in average seasonal $\mathrm{ET}_{\mathrm{c}}$ was found between irrigation methods. These seasonal $\mathrm{ET}_{\mathrm{c}}$ 's are similar to those reported by Fereres and Puech [2]. The $53 \%$ increase in yield between 1970 to 1974 and 2000 to 2004 has not increased the seasonal $\mathrm{ET}_{\mathrm{c}}$, but instead increased the average water use efficiency of processing tomato from $0.079 \mathrm{Mg} \mathrm{ha}^{-1} \mathrm{~mm}^{-1}$ to $0.11 \mathrm{Mg} \mathrm{ha}^{-1} \mathrm{~mm}^{-1}$ over the 35 year period. Mid-season crop coefficients varied between years, but similar values were found between irrigation methods for a given year.

It is unlikely that converting from furrow to drip irrigation in processing tomatoes will reduce seasonal $\mathrm{ET}_{\mathrm{c}}$. While some reduction in water use may occur during the early growth stages, as shown by the 2001 data, the 2002 and 2004 showed that evaporation under furrow irrigation can be reduced by improved water management. Stand establishment with subsurface drip irrigation may reduce $\mathrm{ET}_{\mathrm{c}}$ during the initial growth stage compared to sprinkler irrigation, but this approach is feasible only for transplanted fields. There is little or no opportunity for reduced drip $\mathrm{ET}_{\mathrm{c}}$ during the midseason growth stage because for a given year, similar midseason crop coefficients occurred with both irrigation methods.

\section{References}

[1] California Tomato Growers Association, www.ctga.org/newctga/ production.htm.

[2] Fereres, E. \& Puech, I., Irrigation Scheduling Guide, California Department of Water Resources, 1981.

[3] Phene, C.J., McCormick, R.L. \& Miyamoto, J.M., Evapotranspiration and crop coefficient of trickle-irrigated tomatoes. Proceedings of the Third Drip/Trickle Irrigation Congress, Drip/Trickle Irrigation in Action, November 18-21, Fresno, CA, 1985.

[4] Pruitt, W.O., Lourence, F.J. \& Von Oettingen, S., Water use by crops as affected by climate and plant factors. California Agriculture, 26(10), pp. 10-14, 1972.

[5] Pruitt, W.O., Fereres, E., Martine, P.E., Singh, H., Henderson, D.W., Hagan, R.M., Tarantino, E. \& Chandio, B., Microclimate, evapotranspiration, and water-use efficiency for drip-and furrow-irrigated tomatoes. Twelfth International Congress on Irrigation and Drainage, International Commission on Irrigation and Drainage, Fort Collins, $\mathrm{CO}$, May 28-June 2, 1984. 